\title{
Connecting research to practice to improve energy demand-side management (DSM)
}

\author{
S.C. Breukers ${ }^{\mathrm{a}, *}$, E. Heiskanen ${ }^{\mathrm{b}}$, B. Brohmann ${ }^{\mathrm{c}}$, R.M. Mourik ${ }^{\mathrm{a}}$, C.F.J. Feenstra ${ }^{\mathrm{a}}$ \\ ${ }^{a}$ Energy Research Centre of The Netherlands (ECN), Radarweg 60, 1043 NT Amsterdam, The Netherlands \\ b Öko-Institut e.V., Rheinstraße 95, 64295 Darmstadt, Germany \\ ${ }^{\mathrm{c}}$ National Consumer Research Centre (NCRC), P.O. Box 5, FIN-00531 Helsinki, Finland
}

\section{A R T I C L E I N F O}

\section{Article history:}

Received 29 November 2009

Received in revised form 10 June 2010

Accepted 22 June 2010

Available online $\mathrm{xxx}$

\section{Keywords:}

Energy efficiency

Demand-side management

Behavioural change

Action Research

Transdisciplinarity

Intermediary organisations

\begin{abstract}
A B S T R A C T
Exchange of experience between researchers and practitioners is important for arriving at new knowledge that is translatable into practice and at the same time endures in science. This notion has been central in CHANGING BEHAVIOUR, a project aimed at a better understanding of why energy demand-side management (DSM) programmes succeed or fail. Generally, there is a growing tradition of evaluation that encompasses the co-construction of programmes, technology and context. Nevertheless, most current research and evaluation in this particular area focuses solely on the influence of programme characteristics while overlooking contextual factors and transdisciplinary integration. This paper presents the outcomes of theoretical and empirical work involving new insights regarding the crucial conditions for successful energy DSM programmes. In addition, we demonstrate the usefulness of an Action Research methodology that aims to explicitly promote social change though transdisciplinary collaboration between researchers and practitioners. We conclude that a conceptualisation of energy behavioural change as nested within and interacting with broader social processes differs from existing models that place individual change processes at the centre of attention. The toolbox we developed for and with practitioners (involved in designing and implementing energy demand-side programmes) differs accordingly, among others in that it is context-sensitive.
\end{abstract}

(c) 2010 Elsevier Ltd. All rights reserved.

\section{Introduction}

In recent years energy efficiency and energy conservation have gained renewed interest, as the cheapest and most feasible ways to meet climate change mitigation targets (as well as many other environmental objectives). Concerns about security of supply, 'peak oil' and other resource shortages have added to the urgency of energy conservation [1]. Energy conservation can be achieved partly through energy demand-side management (DSM) programmes

\footnotetext{
* Corresponding author. Tel.: +31 2245682 68; fax: +31 224568339 .

E-mail address: breukers@ecn.nl (S.C. Breukers).

1 Changing Behaviour is supported by the European Commission under its Seventh Framework Programme (contract number: 213217). The project is coordinated by the National Consumer Research Centre (Finland). Other research partners of the consortium include Oeko Institute (Germany), SURF Centre (UK) Central European University (Hungary) and Energy research Centre of the Netherlands (Netherlands). The practitioner-partners include SEI-Tallinn (Estonia) Cowi Baltic (Lithuania), Enespa (Finland), Manchester Knowledge Capital (UK), Green Dependent Sustainable Solutions (Hungary), Ekodoma (Latvia), Verbraucherzentrale Nordrhein-Westfalen (Germany) and Centre for Renewable Energy Sources (Greece). For more information, see www.energychange.info.
}

intended to change the patterns of energy consumption by focusing on end-user energy demand reduction through behavioural changes. In practice it has proven to be very difficult to achieve behavioural changes, and in particular lasting changes, towards more energyefficient consumption patterns [2,3]. This article is based on research and practice within a project entitled CHANGING BEHAVIOUR, ${ }^{1}$ which addresses both the theories about and the practice of behavioural change of energy end-users. We focus on DSM programmes targeted at small-scale energy users, which hold great potential for energy efficiency. They include households, schools, the building sector, municipalities and small and medium-sized enterprises. The DSM practices we are interested in involve two types of energy-related behaviour:

- Efficiency behaviour: one-shot behaviour, i.e. the purchase of energy-efficient equipment and/or appliances.

- Curtailment behaviour: repetitive efforts to reduce energy use.

This distinction is useful because different mechanisms underlie efficiency and curtailment behaviour. Purchasing an energy-efficient appliance is a rather discrete event, preceded by significant 
processing of information and the use of specific decision rules. Interventions intended to change efficiency behaviour target the decision-making process and the rules applied in it. Curtailment, in contrast, refers to types of behaviour that are habitual, less subject to conscious decisions. These types of behavioural changes are difficult to accomplish merely through information and/or incentives. Many DSM programmes target both types of behaviour, e.g. energy audits that advise on efficiency investments as well as on changes in energy usage. Changes in the technologies used and how they are used are both important [4].

For long, the promotion of energy efficiency and the implementation of DSM programmes have been the prerogative of national government and utilities, but this has changed over the past years. Increasingly, intermediary organizations have emerged that address the demand-side of energy efficiency. These intermediaries include specialized energy service companies (ESCOs), government-funded energy agencies, or specific organizations that gain their funding from public benefit charges [5]. When addressing the demand-side of energy, a wide range of relevant stakeholders play a role, from national and local authorities, utilities and retailers, energy auditing specialists, manufacturers of energy-efficient products, financial specialists and non-governmental organizations, to consumers [6].

This paper follows a dual track. The first track (Section 2) presents the theoretical and empirical work done in the CHANGING BEHAVIOUR project, elaborating new insights regarding the crucial conditions to make DSM programmes more successful. In the second track (Section 3) we reflect on the methodology adopted, which combines Action Research and attention for transdisciplinarity - aiming at change and emphasizing researcherspractitioners' interaction. Section 4 concludes on the contribution of a conceptualisation of energy-related behavioural change which is grounded in both theory and practice: a better understanding of the complex dynamics of sociotechnical change involved in DSM programmes which is translated in a practical context-sensitive toolkit for intermediary practitioners.

\section{CHANGING BEHAVIOUR: theoretical and empirical outcomes}

\subsection{Theoretical discussion on behavioural change}

In order to see if academic research on DSM and energy conservation can make a valuable contribution to practical work in the field of DSM, we have reviewed the main lines of research in economics, psychology and social psychology and sociology. ${ }^{2}$ Table 1 summarises these. This section presents our review of these disciplines, focusing on the views of the different disciplines on rationality, barriers to change, appropriate interventions, the dynamics of change and successfulness.

\subsubsection{The rationality of intermediaries and end-users}

Economic and psychological approaches to energy behaviour have been dominant. They highlight factors that relate to information processing and the various aspects that influence energyrelated behaviour on the individual level. These two disciplines host a wide range of assumptions on the rationality of energy end-users. Mainstream neoclassical economics regards energy end-users as fully rational. Many economists however prefer the notion of 'bounded' rationality, which means that there are limits to the amount of information we can sensibly deal with [7]. This is close to

\footnotetext{
${ }^{2}$ For an extensive review, see Deliverable 5 of the CHANGING BEHAVIOUR project (www.energychange.info).
}

the view embraced by cognitive psychology, which focuses on the problems in information processing. Other streams of psychological research have a quite different view of rationality, with behaviourists examining a very narrow but powerful form of learning through the direct consequences of our actions (without any explicit reasoning process) and social psychologists acknowledging the role of social influences on decision-making $[2,8]$.

From these perspectives, programme managers or intermediaries are usually perceived of as being rational. This idea of a rational intermediary, who is trying to change the behaviour of 'less rational' energy end-users appears valid in many ways. It is safe to assume that intermediaries (being full-time professionals) know more about energy use and energy efficiency than the end-users. The picture becomes less valid if we take it to mean that they know more about 'everything', including all sorts of practical problems that endusers experience - see e.g. [9] and [10]. It is also less valid if we assume that the intermediaries are somehow outside the system that they are trying to manage [11]. There are limits to how much information intermediaries can process, too [12]. In addition, they do not only draw on scientific facts (about energy use and behaviour), but also have other resources, such as their relationships with energy end-users and other stakeholders, their own emotions and motivations, their familiarity with local contexts, and their 'tacit' skills and knowledge based on practical experience.

A more realistic view is that end-users and intermediaries are both part of society and work within a certain social structure, a viewpoint emphasized by sociological research on energy use and conservation. Intermediary organizations operate between energy supply and use (or energy policy and energy users). They can facilitate change in the way energy is used. They also work to change the relationships between the actors that they connect [13]. Intermediaries can operate on a 'project' level, providing practical advice and support to energy end-users, or 'delivering' policy programmes like campaigns or audits. But they can also aim for more 'strategic' changes by managing transitions in energy systems and actively seeking to re-shape social practices, institutions and infrastructures.

\subsubsection{Barriers}

Various disciplines have revealed a range of barriers to reducing our demand for energy. These include 'market failures' such as lack of information on the risks and benefits of new solutions, or lack of access to capital for investments $[1,14,15]$. They also include psychological barriers like information overload, lack of direct feedback and lack of perceived 'agency' and capability to make a difference $[2,10,16,17]$. Finally, there are social system barriers [3,18-20] such as existing infrastructures and power relations, shared conventions and historically embedded social practices, i.e. conventional 'ways of doing things' (Table 1, row 4).

\subsubsection{Interventions}

The different disciplines suggest various approaches for reducing energy demand (Table 1, rows 5 and 6). Economists propose to remove barriers by correcting market failures, e.g. providing information (e.g. audits, labels), securing capital for investments (e.g. grants, loans, ESCOs), and supporting research, development and dissemination of energy-efficient solutions [1]. Psychological research suggests a range of solutions for addressing psychological barriers $[2,8,10,21,22]$, among which behavioural interventions to change routines (e.g. triggers, feedback) and improvements in energy-related communication (i.e. making information more relevant, vivid and personal). Social psychology offers ways to address the gap between attitudes/values and behaviour through enabling conditions, increased self-efficacy and agency, and supportive norms and co-operation [23-25]. 
Table 1

Answers to key questions from three disciplinary perspectives.

\begin{tabular}{|c|c|c|c|}
\hline \multirow[t]{2}{*}{ Key question } & \multicolumn{3}{|l|}{ Discipline } \\
\hline & Economics & Psychological and social psychological research & Sociological and sociotechnical research \\
\hline \multirow{4}{*}{$\begin{array}{l}\text { 1. What are the key units of analysis } \\
\text { in energy-related behavioural change? }\end{array}$} & Individuals & Individuals ('Internalised others' - via social norms) & Society \\
\hline & \multirow[t]{3}{*}{ Markets (Institutions) } & & Social practices \\
\hline & & & Sociotechnical networks \\
\hline & & & Systems of provision \\
\hline $\begin{array}{l}\text { 2. What is the logic of action of } \\
\text { programme managers/policy makers? }\end{array}$ & Rational action (public choice) & $\begin{array}{l}\text { Usually rational action (bounded by lack } \\
\text { of psychological competence) }\end{array}$ & $\begin{array}{l}\text { Reflexive: programme managers are part of } \\
\text { the society they are trying to manage, and their } \\
\text { action is influenced by social structures as is the } \\
\text { action of the target group. }\end{array}$ \\
\hline \multirow[t]{2}{*}{ 3. What is the logic of action of target groups? } & Goal-oriented, self-interested & Multiple motivations (self-interested and altruistic) & $\begin{array}{l}\text { Norms-oriented, driven by conventions and } \\
\text { social structure }\end{array}$ \\
\hline & Rational action or bounded rationality & $\begin{array}{l}\text { Experience-, goal- and norm-oriented } \\
\text { Bounded and multiple rationalities }\end{array}$ & $\begin{array}{l}\text { Structurated: actors can also change structures } \\
\text { through action }\end{array}$ \\
\hline \multirow[t]{4}{*}{$\begin{array}{l}\text { 4. What are the barriers to } \\
\text { energy efficiency? }\end{array}$} & \multirow[t]{4}{*}{$\begin{array}{l}\text { Market failures: high cost of information, } \\
\text { externalities, transaction costs }\end{array}$} & $\begin{array}{l}\text { Lack of feedback or information processing capacity } \\
\text { Lack of social pressure } \\
\text { Lack of perceived self-efficacy }\end{array}$ & \multirow[t]{4}{*}{$\begin{array}{l}\text { Embedded in sociotechnical systems: prevailing } \\
\text { infrastructures, conventions, social organization } \\
\text { of the market \& institutions }\end{array}$} \\
\hline & & Lack of skills $\&$ opportunities & \\
\hline & & Habits & \\
\hline & & Helplessness & \\
\hline \multirow{2}{*}{$\begin{array}{l}\text { 5. How can actors be motivated and } \\
\text { mobilised to save energy? }\end{array}$} & \multirow{2}{*}{$\begin{array}{l}\text { By correcting market failures: providing } \\
\text { cheaper information, new institutions, } \\
\text { incentives }\end{array}$} & \multirow{2}{*}{$\begin{array}{l}\text { By providing information, feedback and } \\
\text { (social or economic) incentives in suitable } \\
\text { formats \& combinations }\end{array}$} & Through collective action \\
\hline & & & $\begin{array}{l}\text { Through negotiation and reorganization of } \\
\text { sociotechnical networks }\end{array}$ \\
\hline \multirow{3}{*}{$\begin{array}{l}\text { 6. What intervention instruments } \\
\text { (with relevance to DSM programmes) } \\
\text { have been studied within this tradition? }\end{array}$} & Institutions that correct market failures & Innovative informative instruments & $\begin{array}{l}\text { The same as the others, but from a more } \\
\text { critical perspective }\end{array}$ \\
\hline & \multirow{2}{*}{$\begin{array}{l}\text { Financial instruments } \\
\text { Information (especially audits and feedback) }\end{array}$} & \multirow[t]{2}{*}{ Combinations of information \& incentives } & Change in broader social systems \\
\hline & & & $\begin{array}{l}\text { Social movements } \\
\text { Social innovations }\end{array}$ \\
\hline \multirow{2}{*}{$\begin{array}{l}\text { 7. How do the different traditions evaluate } \\
\text { successful action/successful interventions? }\end{array}$} & \multirow{2}{*}{$\begin{array}{l}\text { Cost-effectiveness } \\
\text { Social welfare (Pareto-optimality) }\end{array}$} & \multirow[t]{2}{*}{ Behavioural change (Social change) } & Social change \\
\hline & & & Social learning \\
\hline
\end{tabular}


Sociological research additionally proposes that we should view change programmes in context. It is not sufficient to deal with individual behaviour, but we also need to change the way energy is supplied and energy-using products are designed and distributed $[3,26]$. We need to address issues of timing, because energy use is largely determined by historical decisions and routines - both on the individual and the societal level [3]. We also need to focus on ideas and social movements that mobilize and align the interests of different actors [20,26]. On a more 'grassroots' level, a sociological approach suggests focusing on group rather than individual change processes [25,27], drawing on local practices rather than merely expert knowledge [9], and involving users in programme design $[26,28-30]$. In order to make a more lasting difference, and indeed work on a more 'strategic' level, we also need to look beyond individual end-users at the networks of actors influencing energyrelated social practices (e.g. lighting, office work, renovating) and engage the related stakeholders in demand-side programmes.

\subsubsection{Addressing change processes}

Existing research rarely deals with or explicitly models the process of change. One perspective, known as the PRECEDE-PROCEED model, has gained some influence in energy DSM practice [31-33]. This model of behavioural change, grounded in work by Green and Kreuter [34], mentions the following types of behavioural determinants that affect changes in behaviour and should therefore be analysed and then targeted:

- Predisposing (motivating) factors: awareness, knowledge, social influence, attitude, social and personal norms, perceived capabilities and self-efficacy

- Enabling factors: financial, technical and organizational resources, new skills

- Reinforcing factors: feedback from peers, experts, authorities and customers

This approach is based primarily on an individualistic view of change, but it also acknowledges the role of the social, physical and institutional environment in change. We refer to context as the physical, social, cultural, economic, institutional and political environment (including various actors) in which the individual operates. It spans from the immediate context of the family, household, workplace and everyday surroundings to national media and policies and to the global economy.

A more contextualised and socially oriented approach to change is embodied in the notion of social learning adopted in the sociology of technology [35]. It is based on historical studies of how new technologies have been adopted in society. Here, change is viewed as a process of negotiation among 'relevant social groups', which can involve debates and controversies, but when successful, results in the embedding of the new solutions in the social context of the energy end-users. In the field of energy, for example, Rohracher [26] has examined how energy-efficient renovations can be promoted by engaging the relevant actors and networks (e.g. residents, facility managers, supply chains, etc.) and actively exploring and developing the social meanings and relations that relate to energy efficiency in buildings. The benefit of this type of change process is that it holds the potential to create a durable network that continues to exist and work also after the intervention.

\subsubsection{Successfulness}

The way in which we study energy DSM also has implications for what is perceived of as successful (Table 1, row 7). A conventional, economic approach evaluates policy interventions from a cost-benefit perspective [36]: programmes should be effective in reducing demand for energy and they should be cost-effective (provide a reasonable return in terms of energy saved compared to the cost of the programme). Less often addressed in the economics literature is the 'political' nature of energy DSM programmes $[20,37]$ : What sort of dynamics do such programmes have, and do they change the nature and patterns of energy demand permanently? Do they mobilize people to continue and expand the changes on their own? Are they a step in a process towards a less energy-intensive lifestyle and society? A more contextual and socially oriented approach suggests the need for new evaluation metrics. Programme evaluations should address the issue of learning (Table 1, row 7). Here, it is important to try to capture processes of social learning, i.e. processes in which the intermediary learns in interaction with the end-users and other stakeholders, and in which this learning changes both the contents and context of the programme.

\subsection{Empirical findings from multiple case analysis and practitioner workshops}

The CHANGING BEHAVIOUR consortium includes researchers and intermediary practitioners who work in the field of DSM. Their tacit and experiential knowledge has informed many aspects of the project, including the selection and subsequent analysis of 24 case studies on past DSM programmes ${ }^{3}$ and the set-up of four workshops with external practitioners. Below we first introduce the method adopted in the empirical work. Next, we present the empirical findings from the multiple case analysis and the workshops.

\subsubsection{Multiple case analysis and workshops: method}

The cases were selected on the basis of several criteria so that they would represent a wide diversity in terms of target groups, countries, initiators, scale, scope, technologies implemented, behavioural change targeted and intervention methodologies used. The data for the single case studies involved programme reports and statistics, as well as interviews with programme managers, policy makers and key programme stakeholders. ${ }^{4}$ To evaluate each case on success or failure, the studies addressed efficiency and effectiveness indicators. Effectiveness refers to the extent to which the programme reached the intended goals, realizing benefits in a broader energy context and in a way that is lasting. Efficiency refers to the efficient use of resources to achieve intended goals and effects. Effectiveness and efficiency assume clarity, lack of ambiguity and consensus regarding the goals. In practice however, in a field like DSM, objectives may (in part) change or have some ambivalence, as well as the instruments adopted. In addition, no single actor controls the whole process. Interaction between different actors (the intermediary, end-users, and other stakeholders) with different ideas may even result in changes in objectives, budgets and time-scales. This learning - the ability to anticipate on or adapt to the specific and changing circumstances - therefore qualified as an important indicator of successfulness as well.

The comparison between cases aimed to identify conditions influencing the success and failure of DSM programmes targeting energy behaviour. A limitation of such of ex post case studies is that they address factors in isolation while in practice they are often intertwined with other conditions. Whether a potentially conducive condition to achieve a certain outcome also will be conducive, depends on how it interacts with other conditions present or absent at that time [38]. We attempted to formulate the relevant

\footnotetext{
3 The Appendix lists the 24 case studies. The extensive multiple case study report is available as Deliverable 4 at www.energychange.info.

${ }^{4}$ The separate case studies are accessible online via a searchable database on www.energychange.info.
} 
conditions as we identified them in such a manner that they capture relational and process characteristics. We tried to formulate themes (see Section 2.2.2) that help us understand how diverse practices have evolved in different contexts and how these shaped actual responses from target-group members.

Four workshops were held in 2008 and 2009 (in Tallinn, Estonia; Budapest, Hungary, Manchester, UK and Athens, Greece). For each workshop, we invited a 'regional' audience of practitioners active in the field of DSM, and more than 170 people participated in total. The aim was to gather knowledge from intermediary practitioners, from outside the CHANGING BEHAVIOUR consortium, to enhance our understanding of the relevant issues in diverse contexts. In subgroups, the participants discussed barriers and opportunities they experience in preparing, designing, implementing and evaluating DSM programmes/projects. In plenary sessions, similarities and difference between sub-groups were further discussed. Afterwards, participants were asked to comment on the workshop reports, which were subsequently published online.

\subsubsection{Outcomes from the multiple case analysis and workshops}

The multiple case analysis revealed the following conditions that are either self-evident or discussed elsewhere extensively $[10,29]$ - but no less important for that matter: sufficient finances and resources, clear focus and goal, sound energy and technical data, continuity and sufficient time for change, regular monitoring and feedback to participants as well as good collaboration with other projects and institutions. In addition, the analysis resulted in several conditions less often discussed in the literature. We have grouped these conditions under themes, presented in Table 2. A common thread throughout the analysis was the finding that particular configurations of context- , actor- and programme-variables produce certain outcomes. ${ }^{5}$

In addition, the workshops resulted in the identification of critical issues in designing and implementing successful DSM programmes (Table 3 ).

The workshops placed the intermediary practitioner in the centre of attention, revealing their diversity in terms of type of organization, background, size, orientation, etc. Intermediaries' roles are not given, but very much dependent on and embedded in the particular context they work in and dependent on the sort of resources they can draw on. Both the context of the practitioner and the context of the enduser were highlighted, the latter more in the case analysis. Both the multiple case analysis and the practitioners' knowledge point to similar important themes that we briefly discuss.

Regarding critical conditions, it was emphasized that there is no single critical condition (no silver bullet). Factors or conditions do not operate in isolation but affect one another (e.g. finance, staffing but also government support and extent to which government is considered trustworthy by citizens). Moreover, each new project presents intermediary practitioners with different combinations of issues, conditions and actors that are relevant in the context of that particular project. This means that a one-size-fits-all approach is not feasible. In line with this, the case analysis concludes that taking context into account is important. Considering bottom-up approaches, alongside top-down ones, can help intermediaries to learn about this context in interaction with relevant stakeholders and target-group members.

In both the case analysis and the workshops, emphasis was placed on the target group in its diversity of roles and identities. Making messages meaningful, an issue discussed frequently in workshops, concerns communication - e.g. introducing new

\footnotetext{
${ }^{5}$ An extensive elaboration of the outcomes of the case studies and the workshops can be found on www.energychange.info.
}

Table 2

Themes relevant for successful DSM programmes. ${ }^{\text {a }}$

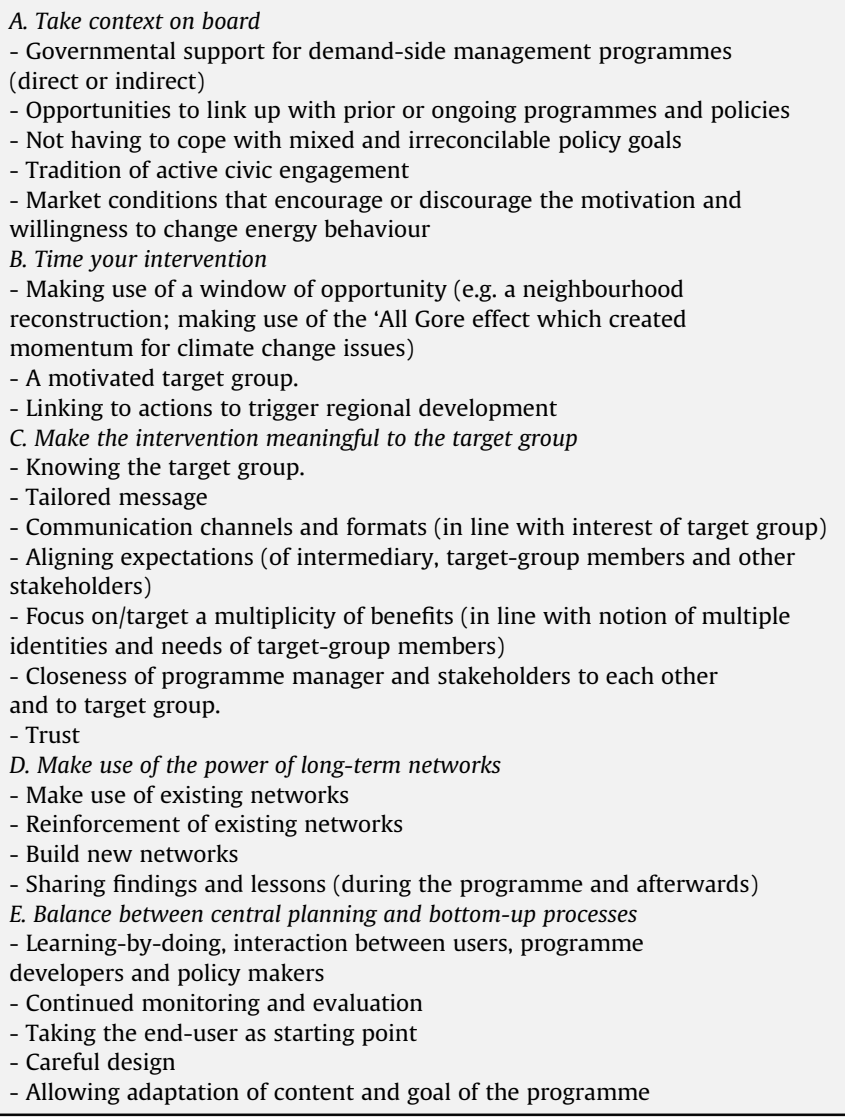

a Outcomes of the multiple case analysis.

(multiple) narratives to replace negative messages. The issue 'making your project meaningful to the target group' (a theme from the case analysis, but also reflected in theory) adds to this the importance of aligning expectations, enabling multiple benefits (acknowledging multiple identities of target-group members), as well as building trust and closeness in the network around the energy DSM project. The workshop pointed out the need to engage: through existing and new networks, diverse knowledge and competences can be engaged in the project, learning can be facilitated and resources from different social arenas can be mobilised.

The issues of evaluation and learning were considered essential during the workshops, with an attention for making learning a routine and for accomplishing effective and appropriate evaluation and learning about the best combination of practices and contexts. The case analysis showed that sharing of findings and lessons (part of the issue of networks) is crucial. The problem, however, is the immediate and resource-limited context within which many intermediaries operate. Triggering learning processes in the face of time and resource limitations remains a difficult challenge.

The broader institutional and policy landscape in which intermediaries operate was discussed in the workshops. The case studies addressed the broader national and local contexts as well demonstrating the need to fine-tune programmes so that they fit with ongoing developments and trends. The practitioners' workshops revealed how different and sometimes contradicting trends affect the operating environment for intermediaries. This raises the question of how intermediaries can anticipate changes and influence their operating environment. Learning and reflection appear crucial again here. 
Table 3

Critical issues in designing and implementing successful DSM programmes. ${ }^{a}$

\begin{tabular}{l}
\hline Critical issues \\
\hline 1. A wide range of interrelated issues and actors are important to successful \\
energy efficiency programmes and projects. \\
2. Understanding, managing and balancing different \\
combinations of issues is the critical challenge \\
3. Beyond a one-size-fits all approach \\
4. Understanding the practical work involved in implementing DSM \\
programmes \\
5. Understanding intermediary context and resources \\
6. Knowing target groups \\
7. Practitioners need to engage with very diverse things \\
8. Making messages meaningful \\
9. Success - evaluation and learning \\
10. Situating the role of intermediaries in relation to policy landscapes
\end{tabular}

a Outcomes of the workshop meetings.

\subsection{New insights for theory and practice}

\subsubsection{New insights for theory}

CHANGING BEHAVIOUR is not the first project that aims to develop a guideline or toolkit to help improve the DSM practice. Several such guidelines have been published over the past years. ${ }^{6}$ Most start from a model of behavioural change that focuses on the individual, from an overall psychological perspective $[33,44]$. Although this model pays attention to contextual influences on behavioural determinants and thus on behavioural changes as well (understood as enabling factors), we argue that this external context should be more in focus. The relationship between individual behaviour and context is a reciprocal one: while individual action is structured by context, context can also be changed by the actions of individuals. We can only (partially) control and influence what an individual sees and reads, not what this individual makes of it. In this understanding, information and persuasion will have an influence on how people talk about these issues and what they see others doing - and as such it will transform the context. What follows from our argument, is that influencing behavioural change is always indirect, namely via the context that subsequently influences individual change. We can distinguish certain factors that are unique to each individual (including determinants of particular behaviours) but they can only be influenced by influencing the context in which the individual operates. The CHANGING BEHAVIOUR behavioural model thus differs from other models (like e.g. the PRECEDE-PROCEED model to which it is most akin) because it addresses specific behaviours (instead of general behaviours); it addresses behaviours in context (instead of decoupled from contexts); it has a particular interest in the social context surrounding and influencing the targeted energy behaviour (instead of focusing on the programme characteristics) and finally because it explicitly addresses the social (and institutional) context as a source of predisposing, enabling and reinforcing factors for change (instead of distinguishing between external and internal factors, delegating external factors to the context and the internal to the individual). In other words, CHANGING BEHAVIOUR proposes a sociotechnical approach, addressing both the individual and the social levels of change, while acknowledging that these changes also take place on different time-scales. Changing the behaviour of an individual by building on the most appropriate motivations,

\footnotetext{
${ }^{6}$ In Deliverable 5 (on www.energychange.info) we have reviewed the following guides: The Guide to Change [39]; BEHAVE [33]; The Art of Changing, behaviour of target groups [31]; a study of the Energy Saving Trust [40]; a report for the UK Environmental Department on pro-environmental behaviour [41]; and two UK publications on climate change communication [42,43].
}

supplying facilitating conditions and reinforcing the change process through positive feedback (as suggested in the PRECEDE-PROCEED model) is a kind of 'social engineering' intervention within a bounded time and space. Issues like securing the resources for this process, gaining social acceptance and support, and making sure that the change process continues after the intervention - and eventually becomes a part of the social structure and culture - are relevant on a broader and more political scale. They cannot be addressed without allowing for conflicts and diverse viewpoints, negotiation and 'translation' of energy conservation in terms of social interests, or the build-up of new social networks and institutions. Thus, the individual change process is nested within - and interacts with - a broader societal change process.

\subsubsection{From theory to practice: starting with the intermediary}

Having coined our sociotechnical approach, we can now turn to the implications of such an approach in practice. The multiple case analysis and the workshops pointed out several issues (Tables 2 and 3 ) that are important to consider for intermediaries in order to better understand and influence change in energy use patterns. These themes are elaborated into practicable tools to help intermediaries to learn about their own position, resources and opportunities to enhance these (e.g. a network analysis identifying actions needed to improve strategic alliances). This is useful because intermediaries are part of the society they are trying to influence. The themes furthermore relate to the durability of the targeted behavioural change; they are about embedding the project by making it 'fit' better.

Intermediaries' action is influenced by social structures and the energy-related behaviours that they attempt to change are also influenced by many other actors and conditions. In addition, different conditions will influence the behaviours of different actors within this configuration differently. Interventions hence should address the whole configuration, not just a targeted group of individuals. An intermediary can try to influence changes towards the targeted energy behaviour by influencing actors and conditions surrounding that behaviour. The target group should therefore be considered and addressed in its social context. An intermediary has to become part of this configuration and to transform it through its interventions. There are several important considerations for such intermediaries.

Intermediaries need to know their own context, the concrete problem of the primary target group, the 'predisposing', 'enabling' and 'reinforcing' factors that affect a behavioural change among this primary target group, the factors and actors influencing the problem, how other players help to predispose, enable, or reinforce the desired behaviours (or, in turn, de-motivate, disable or dampen the desired change), and finally, the extent to which these can be influenced by the intermediary. Intermediaries need to address the relationship between their own programme and other ongoing changes in the context. Adjusting their own goals and ideals to the local practices that they are trying to change may lead to the discovery of 'bottom-up' processes that can support the intermediaries' goals.

\section{Methodology}

The CHANGING BEHAVIOUR project is innovative in respect to its methodology. Although there have been attempts to engage 'nonresearchers' in processes of knowledge development, ${ }^{7}$ such efforts

\footnotetext{
7 e.g. Constructive and Interactive Technology Assessment [49], participatory backcasting and stakeholder dialogue [50,51]; strategic niche management [52] and transition management [53]; Socrobust and ESTEEM [54,55].
} 
have been rare in this field of research. An integrated assessment of complex societal issues implies a combined effort at scientific knowledge generation, practical problem solving capacity and social learning [45-48]. Below we elaborate how we combined the methodologies of Action Research and transdisciplinary research.

\subsection{Connecting methodologies}

There is increasing interest in connecting the traditions of transdisciplinary research and Action Research. ${ }^{8}$ Transdisciplinarity addresses the increasing complexity of environmental problems while Action Research highlights the need for interaction between research and practice in order to contribute to solving societal problems.

Action Research originated in research on organizational change and learning [56-59]. It has since become popular in organizational development, and it is also applied in development research, education, community development, social work and healthcare [60]. It has furthermore gained ground in environmental research and planning [61-63]. Regardless of many varieties of Action Research, some fundamental methodological principles are widely shared $[57,64]$. These include collaborative inquiry by researchers and those whose practice is being studied and the creation of effective action and change in a particular context [65]. As a common methodological principle, Action Research creates new knowledge through multiple cycles of (1) planning, (2) action, (3) observation and (4) reflection [66] in collaboration by researchers and practitioners. Finally, Action Research aims at leaving those involved with lasting capacity $[67,68]$.

The concept of transdisciplinarity is grounded in the philosophy of science [69] and the sociology of science and technology. In the mid-nineties, Gibbons et al. [47] proposed three main principles of transdisciplinary research: heterogeneity, social responsibility and contextuality. Facing the complexity of new (sustainability) problems, the diversity of different views on these problems, and acknowledgement of the societal embeddedness of problem definition and problem solving, the integration of different types of knowledge was considered essential to find new solutions to sustainability challenges. Knowledge production under these three principles was named 'mode 2' in contrast to the traditional type of 'mode 1 ' academic research $[46,70,71]$. Based on a Pragmatist epistemology [64,72], Action Research builds on the three principles that are commonly held in transdisciplinary research. Transdisciplinary research shares with Action Research some important normative and epistemological premises, namely:

- the need to involve 'lay' or 'practitioner' knowledge in order to arrive at problem definitions that are relevant for daily practice and not just for scientific exercise within a particular disciplinary field

- the need to involve and integrate different types of knowledge (scientific, lay, experiential, tacit) and to acknowledge the role of values

- the need for collaborative and interactive processes in order to assess diverse knowledge and perspectives on complex issues and to actively construct new knowledge

- the notion that knowledge about problems and solutions (e.g. in energy efficiency) does not only derive from 'above' or from outside the users' context - innovative practices can also arise from the local context and from users' everyday experiences

- a view of change as occurring in interaction between experts (e.g. energy practitioners) and lay people (e.g. energy users).

\footnotetext{
8 See e.g. Journal of Transdisciplinary Environmental Studies.
}

\subsection{Transdisciplinary Action Research}

Action Research offers a useful approach to deal with complex and multi-faceted problems that involve multiple actors. In contrast to established ways of working within scientific disciplines, CHANGING BEHAVIOUR is transdisciplinary in that it brings together actors from different backgrounds, perspectives, interests, work cultures and knowledge bases. In such heterogeneous networks, interactive research becomes an iterative learning process. The collaboration between practitioners and researchers means that practitioners are involved from the start of the research: their experience is a fundamental resource for the project, and the project aims to help them expand it. In line with this, CHANGING BEHAVIOUR aims at both change and the generation of new knowledge.

The approach involves learning cycles: planning, action, observation and reflection, whereby knowledge is both assessed, produced, and tried out in practice through the interaction between researchers and practitioners. So 'plans' are tested in action, the consequences of the action are evaluated, leading to new plans. Outcomes are further developed into tools which are tested in pilots (after yet another learning cycle).

Contrasting the CHANGING BEHAVIOUR methodology to existing approaches for inquiring into and proposing solutions for energy-related behavioural change, the innovative character of our project relates to the following:

- Our conceptualisation moves beyond the level of the individual when inquiring and addressing change processes.

- We acknowledge the importance of learning-by-doing: knowledge is gained through observing consequences of intentional actions.

- Knowledge is considered as situated: people cannot stand outside the world and observe it - this goes for both researchers and practitioners.

- Our project explicitly addresses change processes as contextualised. From this understanding, it follows that problems and solutions are more multi-faceted than disciplinary research suggests.

- While much research is never used for improving daily practice and as such contributes little to solving real-life problems, we actively make an effort to change this, through our different approach.

This approach requires appropriate project management procedures (e.g. iterative knowledge development; self-reflection through workshops; clarity on roles and responsibilities). These procedures for common problem definition and project design promote the integration of the practitioners' knowledge into the scientific problem definition and research process. The integration of the practitioners' views and experience through active participation in the research process enables a common reflection on the relevant issues and adequate problem solving steps. The premises of integration and reflection demand transparency on common goals and values of the project team as a whole (scientists and practitioners). Besides cognitive integration, social integration (joint activities, interaction of equals) is also necessary for genuine knowledge-sharing.

\section{Conclusion: context as key}

Both the theoretical and empirical works of the CHANGING BEHAVIOUR project have pointed out that behavioural changes need to 'fit' within the context in order to become durable. The conceptual model as developed within the CHANGING BEHAVIOUR 
differs from most existing models that are based on an overall psychological understanding of individual behavioural change while overlooking the importance of the context. It conceptualises individual change processes as nested within - and interacting with - a broader societal change process. In addition, intermediaries' roles are not given, but very much dependent on and embedded in the particular context they work in and dependent on the sort of resources they can draw on.

This sociotechnical conceptualisation of energy-related behavioural change has been translated in a set of 'tools' intended to help intermediaries in planning and implementing energy DSM projects. The tools are tested in pilot projects and subsequently further developed into a toolkit for designing and implementing DSM programmes. ${ }^{9}$ This context-sensitive toolkit encourages intermediaries to learn about the context in which they operate; the sort of behavioural change aimed at; the predisposing, enabling and reinforcing conditions; the various stakeholders that are relevant; the (potential) target groups and how these are affected by predisposing, enabling and reinforcing conditions (including other stakeholders); and about how this environment can be influenced in order to accomplish the targeted behaviour. The development and deployment of this practicable model results from our Action Research methodology that aims at promoting social change though transdisciplinary collaboration between researchers and practitioners.

\section{Uncited references}

$$
[39,40-43,49-55] \text {. }
$$

\section{Acknowledgement}

The research project CHANGING BEHAVIOUR is supported by the European Commission under its Seventh Framework Programme (contract number: 213217).

\section{Appendix. Overview of cases analysed in CHANGING BEHAVIOUR}

\begin{tabular}{|c|c|c|}
\hline Country & Name of DSM programme & Aim of the programme \\
\hline C1. Netherlands & Green energy train Den Haag & $\begin{array}{l}\text { Reduce the energy, heat and water use in apartment houses } \\
\text { by } 5 \% \text { through a specific education and communication approach }\end{array}$ \\
\hline C2. Netherlands & Green energy train Leidsche Rijn & $\begin{array}{l}\text { Reduce the energy, heat and water use in apartment houses by } \\
5 \% \text { through a specific education and communication approach }\end{array}$ \\
\hline C3. Hungary & Global Environmental Social Business Mechanism & Implement energy renovations in apartment blocks \\
\hline C4. Finland & WWF Green Office programme & $\begin{array}{l}\text { Certification and management scheme to reduce } \mathrm{CO}_{2} \text { and } \\
\text { resource consumption in offices }\end{array}$ \\
\hline C5. Finland & Ilmari Climate Change Campaign for Schools & $\begin{array}{l}\text { School climate change awareness campaign implemented } \\
\text { by environmental and youth NGOs }\end{array}$ \\
\hline C6. Latvia & EnERLIn - Efficient Residential Lighting Initiative & $\begin{array}{l}\text { Increase the efficiency of residential lighting by } 50 \% \text { increase in } \\
\text { CFL penetration via promotion campaign and quality charter }\end{array}$ \\
\hline C7. Germany & ETT. EcoTopTen initiative & $\begin{array}{l}\text { Nation-wide information and rating } \\
\text { service for energy-efficient products }\end{array}$ \\
\hline C8. Hungary & Energy Trophy & $\begin{array}{l}\text { Competition for saving energy in office buildings through change } \\
\text { in employee behaviour. }\end{array}$ \\
\hline C9. UK & CIS Co-operative Insurance Society Solar Tower & Renovate a landmark building using solar panels \\
\hline C10. Finland & Energy expert program & $\begin{array}{l}\text { Training of volunteer residents promoting energy } \\
\text { efficiency in housing associations }\end{array}$ \\
\hline C11. Germany & Contracting Rommerskirchen & $\begin{array}{l}\text { Implementation of energy performance } \\
\text { contracting for municipal buildings }\end{array}$ \\
\hline C12. Lithuania & Modernisation Multi-apartment programme & $\begin{array}{l}\text { Promote energy modernisation of multi-apartment buildings } \\
\text { via demonstrations and subsidies }\end{array}$ \\
\hline C13. Lithuania & Taupukas residential awareness campaign & $\begin{array}{l}\text { Communicate the benefits of energy and water consumption } \\
\text { efficiency and stimulate energy and water saving }\end{array}$ \\
\hline C14. Germany & Off-Really Off? & $\begin{array}{l}\text { State-wide campaign to create awareness of standby } \\
\text { energy among consumers and retailers }\end{array}$ \\
\hline C15. UK & Metropolitan Police Energy Efficiency Programme & $\begin{array}{l}\text { Improve energy efficiency improve energy efficiency in } \\
\text { existing buildings and practices of the Metropolitan Police Service }\end{array}$ \\
\hline C16. Hungary & Climate Watch & $\begin{array}{l}\text { Educational and award programme for } \\
\text { school groups to reduce } \mathrm{CO}_{2} \text { emissions }\end{array}$ \\
\hline C17. Hungary & Carbonarium Association & $\begin{array}{l}\text { Produce information on participants' personal climate } \\
\text { change impacts and promote public awareness }\end{array}$ \\
\hline C18. Denmark & Samsø & Creation of a renewable, energy self-sufficient island municipality \\
\hline C19. Finland & Municipal Energy Efficiency Agreements & $\begin{array}{l}\text { Negotiated agreement to promote energy } \\
\text { audits and investments in municipalities }\end{array}$ \\
\hline C20. Latvia & Building energy audits & Energy audits of apartment blocks \\
\hline C21. Germany & SANIT & $\begin{array}{l}\text { On-site advice service for energy efficiency } \\
\text { renovations provided by consumer NGO }\end{array}$ \\
\hline C22. UK & MiMP Climate Change Pledge & $\begin{array}{l}\text { Attract citizens in Greater Manchester to sign up to a } \\
\text { Climate Change Pledge, with information and marketing } \\
\text { to encourage a switch to less carbon-intensive lifestyles. }\end{array}$ \\
\hline C23. Estonia & KRED-EX Energy Saving Competence Centre & $\begin{array}{l}\text { Promotion and knowledge networks on energy } \\
\text { saving measures in apartment buildings }\end{array}$ \\
\hline C24. UK & Manchester is My Planet (MiMP) programme & $\begin{array}{l}\text { Increase policy development/implementation on Climate } \\
\text { Change among Greater Manchester local authorities }\end{array}$ \\
\hline
\end{tabular}

\footnotetext{
${ }^{9}$ The final version will be ready and available online by the end of 2010 .
} 


\section{References}

[1] Geller H, Attali S. The experience with energy efficiency policies and programmes in IEA countries. Learning from the Critics. Paris: International Energy Agency (IEA); 2005.

[2] Kurz T. The psychology of environmentally sustainable behaviour: fitting together pieces of the puzzle. Analysis of Social Issues and Public Policy 2002;2(1):257-78.

[3] Wilhite H, Shove E, Lutzenhiser L, Kempton W. The legacy of twenty years of energy demand management: we know more about individual behaviour but next to nothing about demand. In: Jochem E, Sathaye JA, Bouille J, editors. Society, behaviour, and climate change mitigation. Dordrecht: Kluwe Academic Publishers; 2000. p. 109-26.

[4] Wilhite $\mathrm{H}$. Will efficient technologies save the world? A call for new thinking on the ways that end use technologies affect energy using practises. In: Attalli S, Tillerson K, editors. Saving energy - just do it! Proceedings of the ECEEE Summer Study La Colle sur Loup, France/Stockholm: European Council for an Energy Efficient Economy (ECEEE); 2007 June 4-9. p. 23-31.

[5] Didden MH, D'haeseleer WD. Demand side management in a competitive European market: who should be responsible for implementation? Energy Policy 2003;31(3):1307-14.

[6] Kant AD. Strategies and instruments to promote energy efficiency in developing countries. Project working paper 5.. Energy Research Centre of the Netherlands (ECN); 1995. Report no ECN-C-94-113

[7] March JG, Simon HA. Organizations. New York: John Wiley \& Sons; 1958.

[8] Abrahamse W, Steg L, Vlek C, Rothengatter T. A review of intervention studies aimed at household energy conservation. Journal of Environmental Psychology 2005;25(4):273-91.

[9] Guy S, Shove E. A sociology of energy, buildings and the environment: constructing knowledge, designing practice. New York: Taylor \& Francis Ltd; 2000.

[10] Parnell R, Larsen OP. Informing the development of domestic energy efficiency initiatives. An everday householder-centred perspective. Environment and Behaviour 2005;37(6):787-807.

[11] Green K, Hull R, McMeekin A, Walsh V. The construction of the technoeconomic: networks vs. paradigms. Research Policy 1999;28(7):777-92.

[12] Cohen WM, Levinthal DA. Absorptive capacity: a new perspective on learning and innovation. Administrative Science Quarterly 1990;35:128-52.

[13] Hodson M, Marvin S. Cities mediating technological transitions: understanding visions, intermediation and consequences. Technology Analysis and Strategic Management 2009;21(4):515-34.

[14] Golove WH, Eto JH. Market barriers to energy efficiency: a critical reappraisal of the rationale for public policies to promote energy efficiency. California: Lawrence Berkeley National Laboratory; 1996.

[15] Sorrell S. The economics of energy service contracts. Energy Policy 2006;35 (1):507-21.

[16] Kaplan S. Human nature and environmentally responsible behaviour. Journal of Social Issues 2000;56(3):491-508.

[17] Thøgersen J. How may consumer policy empower consumers for sustainable lifestyles? Journal of Consumer Policy 2005;28(2):143-77.

[18] Shove E. Converging conventions of comfort, cleanliness and convenience. Journal of Consumer Policy 2003;26:395-418

[19] Van Vliet B, Chappells H, Shove E. Infrastructures of consumption. Environmental innovation in the utility industries. London: Earthscan; 2005.

[20] Biggart NW, Lutzenhiser L. Economic sociology and the social problem of energy inefficiency. American Behavioral Scientist 2007;50(8):1070-87.

[21] Stern PC. Toward a coherent theory of environmentally significant behaviour. Journal of Social Issues 2000;56(3):407-24.

[22] Stern PC. Information, incentives and pro environmental consumer behaviour. Journal of Consumer Policy 1999;22:461-78.

[23] Kaiser FG, Wölfing S, Fuhrer U. Environmental attitude and ecological behaviour. Journal of Environmental Psychology 1999;19:1-19.

[24] Olli E, Grendstad G, Wollebaek D. Correlates of environmental behaviors: bringing back social context. Environment and Behaviour 2001;33:181-208.

[25] Lucas K, Brooks M, Darnton A, Jones JE. Promoting pro-environmental behaviour: existing evidence and policy implications. Environmental Science and Policy 2008;11:458-66.

[26] Rohracher H. Managing the technological transition to sustainable construction of buildings: a socio-technical perspective. Technology Analysis and Strategic Management 2001;13(1):137-50.

[27] Jackson T. Motivating sustainable consumption - a review of models of consumer behaviours and behavioural change. A Report to the Sustainable Development Research Network; 2005. London.

[28] Rohracher $\mathrm{H}$. The role of users in the social shaping of environmental technologies. Innovation 2003;16(2):177-92.

[29] Aune M, Berker T, Sørensen KH. Needs, roles and participation: a review of social science studies of users in technological design. A report within the research program Smart Energy-Efficient Buildings. Trondheim: NTNU, Department of Interdisciplinary Studies of Culture; 2002.

[30] Midden CJH, Kaiser F, McCalley T. Technology's four roles in understanding individuals' conservation of natural resources. Journal of Social Issues 2007;63 (1):155-74

[31] Egmond C, Jonkers R, Kok G. One size fits all? Policy instruments should fit the segments of the target group. Energy Policy 2006;34:3463-74.
[32] Uitdenbogerd D, Egmond C, Jonkers R, Kok G. Energy-related intervention success factors: a literature review. Proceedings of the ECEEE Summer Study. In: Attalli S, Tillerson K, editors. Saving energy - just do it! La Colle sur Loup, France/Stockholm: European Council for an Energy Efficient Economy (ECEEE); 2007 June 4-9. p. 1847-55.

[33] Dahlbom B, Greer H, Egmond C, Jonkers R. Changing energy behaviour: guidelines for behavioural change programmes. Report by the BEHAVE project; 2009 [Supported by Intelligent Energy Europe Programme of the European Commission].

[34] Green LW, Kreuter MW. Health program planning: an educational and ecological approach. New York: McGraw-Hill; 2005.

[35] Russell S, Williams R. Social shaping of technology: frameworks, findings and implications for policy. In: Sørensen K, Williams R, editors. Shaping technology, guiding policy. Cheltenham: Edward Elgar; 2002.

[36] Vreuls H. Evaluating energy efficiency policy measures \& DSM programmes. In: Country reports and case examples used for the evaluation guide book, vol. II. Paris: International Energy Agency Demand-Side Management Programme; 2005. IEA-DSM Programme.

[37] Kempton W, Darley JM, Stern PC. Psychological research for new energy problems. American Psychologist 1992:47(10):1213-23.

[38] Pawson R, Tilley N. Realistic evaluation. London: Sage Publications; 1997.

[39] Greer H, Jonkers R, Smits A, Görts C, Papadopoulou K, Begley S. The guide to change. Energy related behaviour. A SAVE study. Boxtel: Aeneas, Technical Publishers; 2001.

[40] Energy Saving Trust. Climate change and sustainable energy: information for scrutiny members and policy reviewers. Briefing Note [updated Jan 2008; cited June 2010]. Available from: www.energysavingtrust.org.uk.

[41] Darnton A, Elster-Jones J, Lucas K, Brooks M. Promoting pro-environmental behaviour: existing evidence to inform better policy making; 2008. A Study for the Department for Environment, Food and Rural Affairs (Defra).

[42] Futerra. The rules of the game. Principles of climate change communications; 2005. London.

[43] Futerra. New rules: new game. Communications tactics for climate change; 2006. London.

[44] Egmond C. De kunst van het veranderen. Gedrag van doelgroepen; 2003. Utrecht.

[45] Brohmann B. Die Praxis der Qualitätssicherung in der Nachhaltigkeitsforschung. In: Bergmann M, Schramm E, editors. Transdisziplinäre Forschung. Integrative Forschungsprozesse verstehen und bewerten; 2008. p. 103-25. Frankfurt/New York

[46] Ravetz J. Science and sustainability. Science and technology policies in Europe: new challenges, new responses. Proceedings and final reports of the STRATA Consolidating workshop; 2002 Apr 22-23 [Brussels, Belgium].

[47] Gibbons M, Limoges C, Nowotny H, Schwartzman S, Scott P, Trow M. The new production of knowledge. London: SAGE Publications Ltd; 1994.

[48] Nowotny H, Scott P, Gibbons M. 'Mode 2' revisited: the new production of knowledge - introduction. Minerva 2003;41:179-94.

[49] Rip A, Misa TJ, Schot J, editors. Managing technology in society - the approach of constructive technology assessment. London: Pinter; 1995.

[50] Quist J, Vergragt P. Past and future of backcasting: the shift to stakeholder participation and a proposal for a methodological framework. Futures 2006;38:1027-45.

[51] Cuppen E, Breukers S, Hisschemöller M, Bergsma EQ. Methodology to select participants for deliberative processes on the basis of perspectives rather than organisation: application in a stakeholder dialogue on energy options from biomass in The Netherlands. Ecological Economics 2009;69(3):579-91.

[52] Kemp R, Schot JW, Hoogma R. Regime shifts to sustainability through processes of niche formation: the approach of strategic niche management Technology Analysis and Strategic Management 1998;10:175-96.

[53] Rotmans J, Kemp R, Van Asselt M. More evolution than revolution: transition management in public policy. Foresight 2001;3(1):15-31.

[54] Jolivet E, Laredo P, Shove E. Managing breakthrough innovations: the SOCROBUST methodology. Paper presented at the Annual Conference R\&D Management, 8-9 July 2002, Leuven, Belgium.

[55] Poti BM, Mourik RM, Raven RPJM, Jolivet E, Alcantud A, Torrent D, et al. Manual on the Socrobust tool and recent experiences with using Socrobust. Petten: ECN Policy Studies; 2007. Paper for the Create Acceptance project.

[56] Lewin K.. Experiments in social space. Reprinted in Reflections 1999;1(1) 7-13.

[57] Argyris C, Putnam R, McLain Smith D. Action science: concepts, methods, and skills for research and intervention. San Francisco: Jossey-Bass; 1985.

[58] Cunninham JB. Action research and organizational development. Westport, CT: Praeger Publishers; 1993.

[59] Snyder M. In the footsteps of Kurt Lewin: practical theorizing, action research and the psychology of social action. Journal of Social Issues 2009;65 (1):225-45.

[60] Dick B. Action research literature 2004-2006: themes and trends. Action Research 2006;4(4):439-58.

[61] Hobson K. Thinking habits into action: the role of knowledge and process in questioning household consumption practices. Local Environment 2003;8 (1):95-112.

[62] Quist JN, Vergragt PJ. System innovations towards sustainability using stakeholder workshops and scenarios. Paper for Policy Agendas for Sustainable Technological Innovation. 3rd POSTI International Conference; 1-3 Dec 2000 [London, United Kingdom]. 
[63] Elfors S, Svane Ö. Action research for sustainable housing: theoretical and methodological implications of striving for research as a tool for change. Journal of Transdisciplinary Environmental Studies 2009;7(2).

[64] Kemmis S, McTaggart R. Participatory action research. In: Denzin NK, Lincoln YS, editors. Handbook of qualitative research. Thousand Oaks, CA: Sage; 2000. p. 567-606.

[65] Reason P, Bradbury H. Handbook of action research. London: Sage; 2001.

[66] Reason P, Torbert WR. The action turn towards a transformational social science. Concepts and Transformations 2001;6:1-37.

[67] Melrose MJ. Maximising the rigor of action research: why would you want to? How could you? Field Methods 2001;13(2):160-80.

[68] Bradbury H, Reason P. Action research: an opportunity for revitalising research purposes and practices. Qualitative Social Work 2008;2:155-75.
[69] Mittelstraß J. Die Stunde der Interdisziplinarität? In: Kocka J, editor. Interdisziplinarität. Praxis - Herausforderung - Ideologie. Frankfurt/Main: Suhrkamp; 1987.

[70] Jahn T. Transdisziplinarität in der Forschungspraxis. In: Bergmann M Schramm E, editors. Transdisziplinäre Forschung. Integrative Forschungsprozesse verstehen und bewerten. Frankfurt/New York: Campus Verlag; 2008. p. 21-37.

[71] Bergmann M, Brohmann B, Hoffmann E, Loibl MC, Rehaag R, Schramm E, et al. Quality criteria of transdisciplinary research. A guide for the formative evaluation of research projects. ISOE-Studientexte, Report No 13; 2005. Frankfurt am Main.

[72] Reason P. Pragmatist philosophy and action research: readings and conversation with Richard Rorty. Action Research 2003;1(1):103-23.

Please cite this article in press as: Breukers SC, et al., Connecting research to practice to improve energy demand-side management (DSM), Energy (2010), doi:10.1016/j.energy.2010.06.027 